\title{
Behaviour of fibre-reinforced high-performance concrete in exterior beam-column joint
}

\author{
P. Muthupriya $\cdot$ S. C. Boobalan $\cdot$ B. G. Vishnuram
}

Received: 5 July 2013/ Accepted: 13 December 2013/Published online: 7 August 2014

(c) The Author(s) 2014. This article is published with open access at Springerlink.com

\begin{abstract}
This paper presents the effect of reinforced high performance concrete (HPC) in exterior beam-column joint with and without fibre under monotonic loading. In this experimental investigation, cross-diagonal bars have been provided at the joint for reducing the congestion of reinforcement in joints, and also M75 grade of concrete with optimum mix proportion of $10 \%$ silica fume and $0.3 \%$ glass fibre was used. Four exterior beam-column joint sub-assemblages were tested. The specimens were divided into two types based on the reinforcement detailing. Type A comprises two joint sub-assemblages with joint detailing as per construction code of practice in India (IS 456-2000), and Type B comprises two joint subassemblages with joint detailing as per ductile detailing code of practice in India (IS 13920-1993). In each group there was one specimen of control mix and the remaining one specimen of fibre-reinforced mix. All the test specimens were designed to satisfy the strong column-weak beam concept. The performances of specimens were compared with the control mix and the fibre-reinforced mix. The results show that exterior beam-column joint specimens with silica fume and glass fibre in the HPC mix showed better performance.
\end{abstract}

Keywords Exterior beam-column joint - Highperformance concrete Silica fume Glass fibre Monotonic loading

P. Muthupriya $(\bowtie) \cdot$ S. C. Boobalan

Sri Krishna College of Technology, Coimbatore 641 042, India

e-mail: muthupriya.vlb@gmail.com

B. G. Vishnuram

Easa College of Engineering and Technology,

Coimbatore 641105, India

\section{Introduction}

In reinforced concrete buildings, portions of columns that are common to beams at their intersections are called beam-column joint. Their constituent materials have limited strength; the joints have limited force carrying capacity. When forces larger than these are applied during earthquake, joints are severely damaged. There are three types of joints that can be identified, viz., interior joint, exterior joint and corner joint. While comparing the three types of joints, exterior beam-column joint will be the most affected under any external loading. In exterior joints where beams terminate at columns, longitudinal beam bars need to be anchored into the column to ensure proper gripping of bar in joint. Recent earthquakes in different parts of the world have revealed again the importance of design of reinforced concrete structures with high ductility. Strength and ductility of structures depend mainly on proper detailing of the reinforcement in beam-column joints. The flow of forces within a beamcolumn joint may be interrupted if the shear strength of the joint is not adequately provided for. Under seismic excitations, the beam-column joint region subjected to horizontal and vertical shear forces whose magnitude is many times higher than those within the adjacent beams and columns. However, fibre concrete can sustain a portion of its resistance following cracking to resist more cycles of loading (Ganeshan et al. 2007). Due to the congestion of reinforcement, casting of beam-column joint will be difficult and will lead to honeycombing in concrete (Kumar et al. 1991).

Damages in reinforced concrete structures are mainly attributed to shear force due to the inadequate detailing of reinforcement and lack of transverse steel and confinement of concrete in structural elements. 
Table 1 Concrete mix proportions

\begin{tabular}{llllllll}
\hline Mix & MCS & MSF1 & MSF1G3 & MSF1G6 & MSF2 & MSF2G3 & MSF2G6 \\
\hline Cement $\left(\mathrm{kg} / \mathrm{m}^{3}\right)$ & 583 & 525 & 525 & 525 & 466 & 466 & 466 \\
FA $\left(\mathrm{kg} / \mathrm{m}^{3}\right)$ & 602 & 602 & 602 & 602 & 602 & 602 & 602 \\
CA $\left(\mathrm{kg} / \mathrm{m}^{3}\right)$ & 1,151 & 1,151 & 1,151 & 1,151 & 1,151 & 1,151 & 1,151 \\
SF $(\%)$ & 0 & 10 & 10 & 10 & 20 & 20 & 20 \\
GF $(\%)$ & 0 & 0 & 0.3 & 0.6 & 0 & 0.3 & 0.6 \\
Water $\left(\mathrm{lit} / \mathrm{m}^{3}\right)$ & 151 & 151 & 151 & 151 & 151 & 151 & 151 \\
Superplasticizer $\left(\mathrm{lit} / \mathrm{m}^{3}\right)$ & 4.7 & 4.7 & 4.7 & 4.7 & 4.7 & 4.7 & 4.7 \\
\hline
\end{tabular}

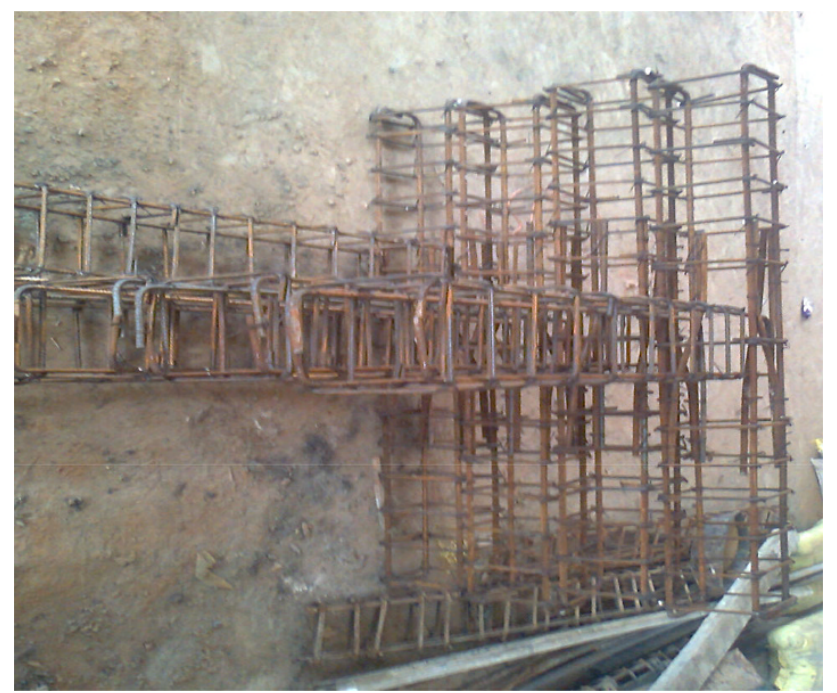

Fig. 1 Reinforcement detailing

Bindhu and Jaya (2008) deal with the non-conventional reinforcement detailing in the beam-column joint by providing inclined bars on the two faces of the joint core, which leads to reduction in compaction and construction difficulties due to congestion of reinforcement in the joint region. Bindhu and Jaya (2010) reported that confinement of core concrete without congestion of reinforcement in joints by providing additional cross bracing bars provided on two faces of joint as confining reinforcements. Perumal and Thanukumari (2010) reported that conventional concrete loses its tensile resistance after formation of cracks; fibre concrete can sustain a portion of its resistance following cracking to resist more cycles of loading. Malathy et al. (2007) investigated the effect of glass fibre on restrained shrinkage cracking in concrete, especially highperformance concrete (HPC) because plastic shrinkage and drying shrinkage were the shortcomings of HPC with those additives like silica fume, metakoaline, fly ash and superplasticizer. The objective of this paper is to study the behaviour of exterior beam-column joint with and without fibre-reinforced HPC and the reinforcement designed as per both IS 456-(2000) and IS 13920-(1993) with cross-diagonal bars at the joint were tested under monotonic loading.

\section{Experimental investigation}

\section{Materials}

\section{Cement}

The ordinary Portland cement of 53 Grade conforming to IS 12269-(1987) was used in this study. The specific gravity, initial and final setting of OPC 53 grade were 3.15 , 30 and $600 \mathrm{~min}$, respectively.

\section{Fine aggregate}

Locally available river sand conforming to grading zone II of IS 383-(1970). Sand passing through IS $4.75 \mathrm{~mm}$ sieve will be used with the specific gravity of 2.65 .

\section{Coarse aggregate}

Locally available crushed blue granite stones conforming to graded aggregate of nominal size $12.5 \mathrm{~mm}$ as per IS 383-(1970) with the specific gravity of 2.77 .

\section{Silica fume}

Silica Fume was obtained from Elkem India (P) Ltd., Navi Mumbai conforming to ASTM C 1240 as mineral admixture in dry densified form.

\section{Glass fibre}

Glass fibre available in the market was used in this experimentation. The length of the fibre is $12 \mathrm{~mm}$ and the diameter of $14 \mu$ with the specific gravity of 2.6.

\section{Water}

Casting and curing of specimens were done with the potable water that is available in the college premises. 


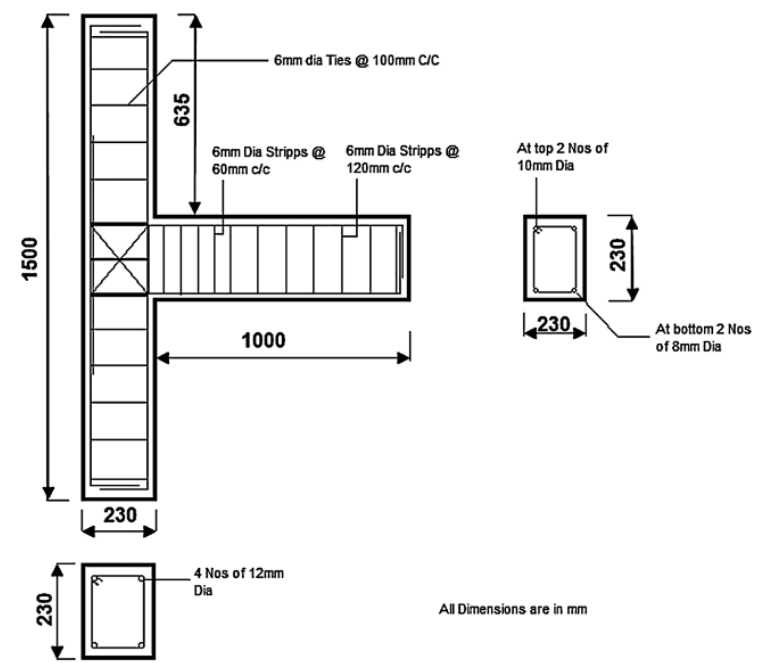

(a) Type A

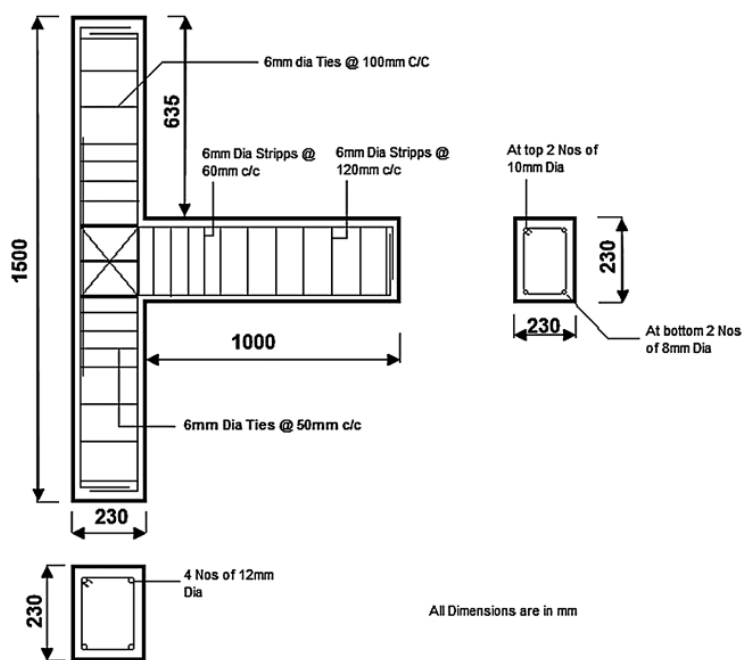

(b) Type B

Fig. 2 Cross section and Reinforcement details of the specimens a Type A (as per IS 456-2000 with cross diagonal bars at the joint), b Type B (as per IS 13920-1993 with cross diagonal bars at the joint)

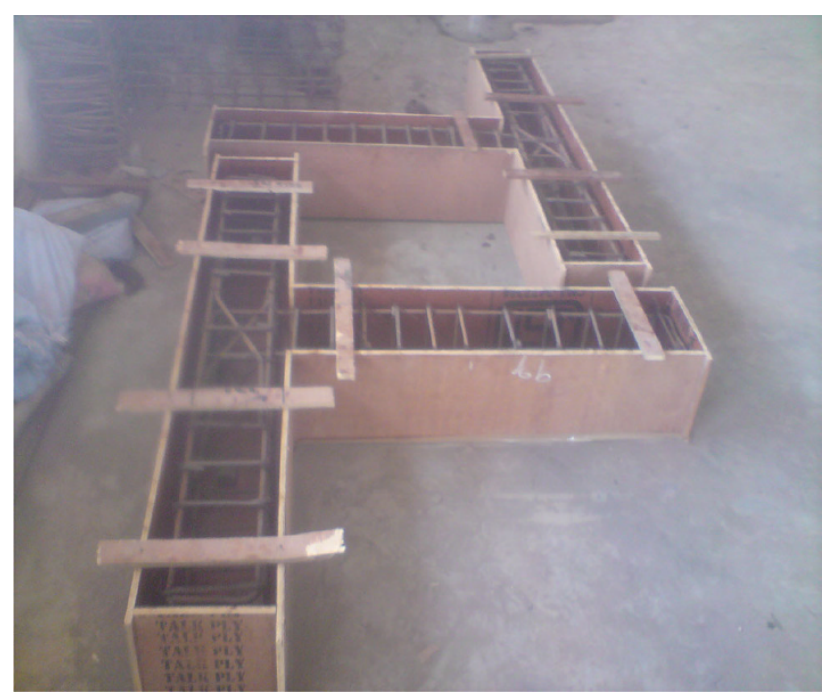

Fig. 3 Formwork and reinforcement

\section{Superplasticizer}

A commercially available sulphonated naphthalene formaldehyde based superplasticizer (Conplast SP 430) was used as chemical admixture to enhance the workability of the concrete.

\section{Mix proportions}

In this study, control specimen (MCS) was designed as per ACI 211.4R-(1993) to achieve M75 grade of concrete. Silica fume was used to replace ordinary Portland cement at various levels of $0,10,20 \%$; and the glass fibres of 0 ,

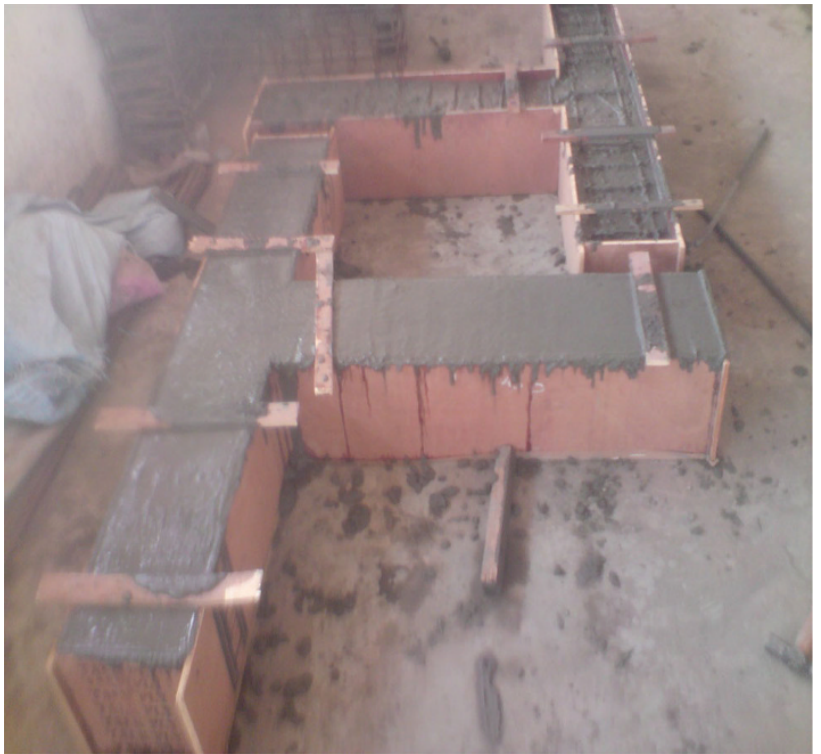

Fig. 4 Casting stage of specimens

$0.3,0.6 \%$ were used. The mix proportions of different mixes are shown in Table 1.

\section{Preliminary studies}

In the preliminary studies, the standard sizes of cube $(150 \times 150 \times 150 \mathrm{~mm})$, cylinder $(150 \mathrm{~mm}$ diameter and $300 \mathrm{~mm}$ height $)$ and prism $(500 \times 100 \times 100 \mathrm{~mm})$ were tested as per IS 516-(1959). The concluding results were as follows: The cube compressive strength was observed as $89.1 \mathrm{~N} / \mathrm{mm}^{2}$ for $10 \% \mathrm{SF}$ and $0.3 \% \mathrm{GF}$ there is an 
increase of strength by $12.5 \%$ when compared to control specimen and for the same with $10 \% \mathrm{SF}$ and $0 \%$ GF there is an increase of strength by $4 \%$. The development of Split tensile strength with ages for the above different mixes was plotted in the form of graph as shown in Fig. 1. The cylinder split tensile strength was observed as $6.330 \mathrm{~N} / \mathrm{mm}^{2}$ for $10 \% \mathrm{SF}$ and $0.3 \% \mathrm{GF}$ there is an increase of strength by $4.4 \%$ when compared to control specimen and for the same with $10 \% \mathrm{SF}$ and $0 \%$ GF there is an increase of strength by $2 \%$. The prism flexural strength was observed as $5.430 \mathrm{~N} / \mathrm{mm}^{2}$ for $10 \% \mathrm{SF}$ and $0.3 \%$ GF there is an increase of strength by $9.4 \%$ when compared to control specimen and for the same with $10 \% \mathrm{SF}$ and $0 \% \mathrm{GF}$ there is an increase of strength by $5 \%$. From the experimental results, the optimum percentage recommended as $0.3 \%$ glass fibre

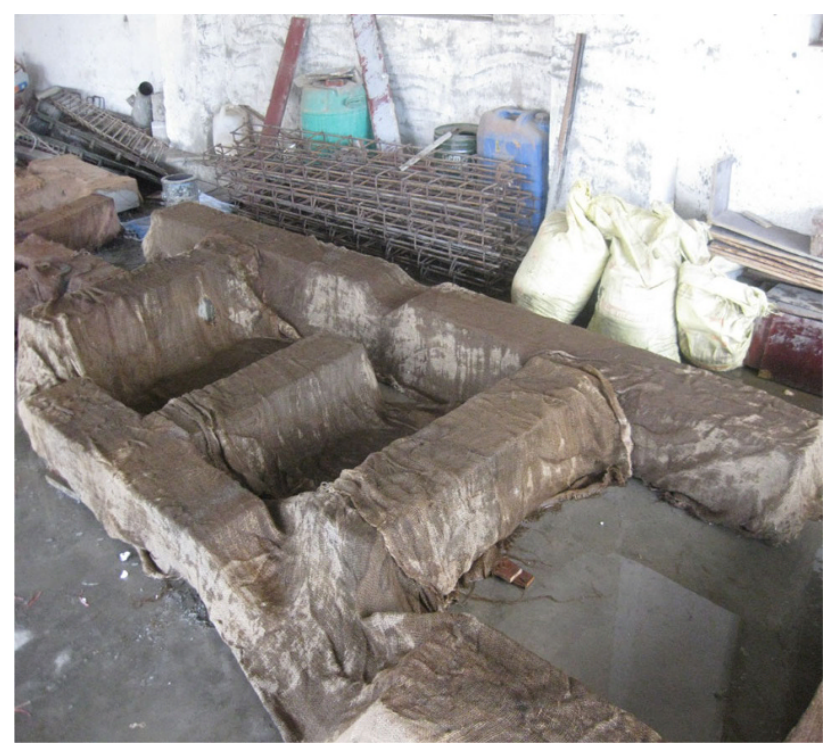

Fig. 5 Specimens under wet curing volume with $10 \%$ silica fume for achieving maximum benefits in compressive, split tensile and flexural strength. These optimum percentages of silica fume and glass fibres in the HPC mix were used in the casting of exterior beam-column joint specimens.

Exterior beam-column joint specimen details

All the four exterior beam-column joints had identical beam and column sizes. The column has a cross section of $230 \mathrm{~mm} \times 230 \mathrm{~mm}$ with an overall length of $1,500 \mathrm{~mm}$ and the beam has a cross section of $230 \mathrm{~mm} \times 230 \mathrm{~mm}$ with a cantilever portion of length $1,000 \mathrm{~mm}$. Figure 2 shows the cross section and reinforcement configuration for the exterior beam-column joint specimens.

Casting and testing of specimens

Plywood moulds were used for casting the specimens. Reinforcement cages were fabricated and placed inside the moulds. Required quantities of cement, sand and coarse aggregate were mixed thoroughly in a drum-type mixer machine and $50 \%$ of water was added to the dry mix. The remaining $50 \%$ water was mixed with the superplasticizer and added along with the silica fume and glass fibre. The mixes were poured into moulds in layers and the moulds were vibrated for thorough compaction. After $24 \mathrm{~h}$ of casting, specimens were demoulded and cured under wet gunny bags for 28 days (Figs. 3, 4, 5).

Specimens were tested in a loading frame of 100 tonne or $1000 \mathrm{kN}$ capacity. A constant load of $150 \mathrm{kN}$, which is about $20 \%$ of the axial capacity of the column was applied to the column for holding the specimens in position. A hydraulic jack of 50 tonne or $500 \mathrm{kN}$ capacity was used to apply load at the beam. A load cell of 50 tonne capacity was used to measure the applied load accurately. The gradual increase of load was applied to the end of the

Fig. 6 Schematic diagram of monotonic loading test set-up

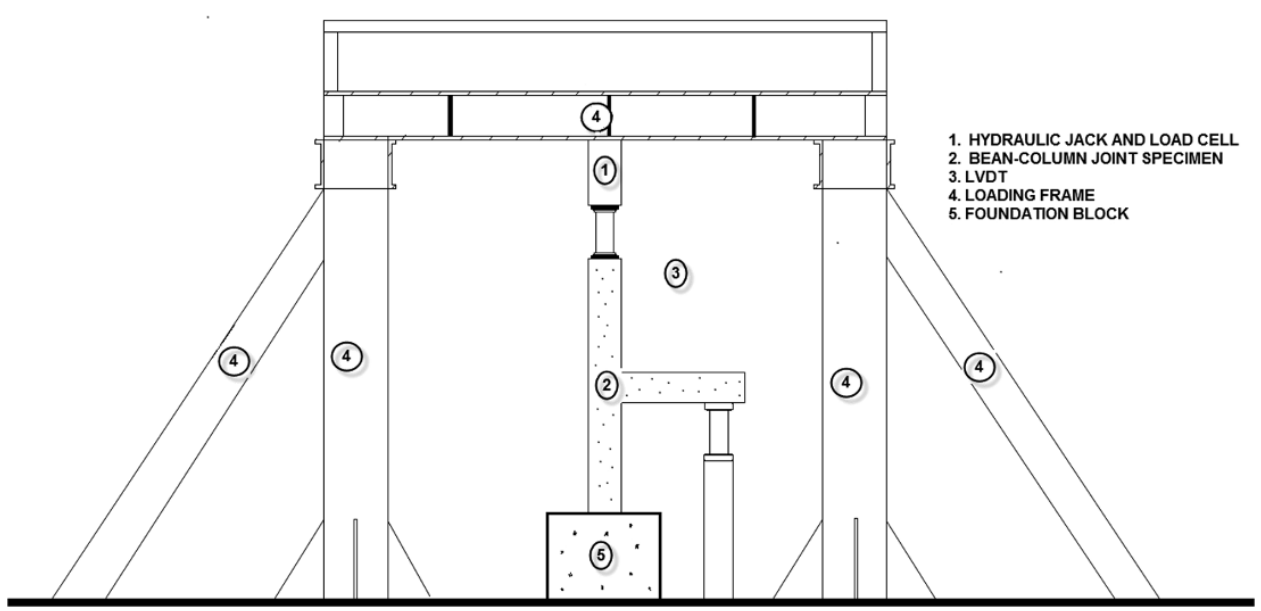




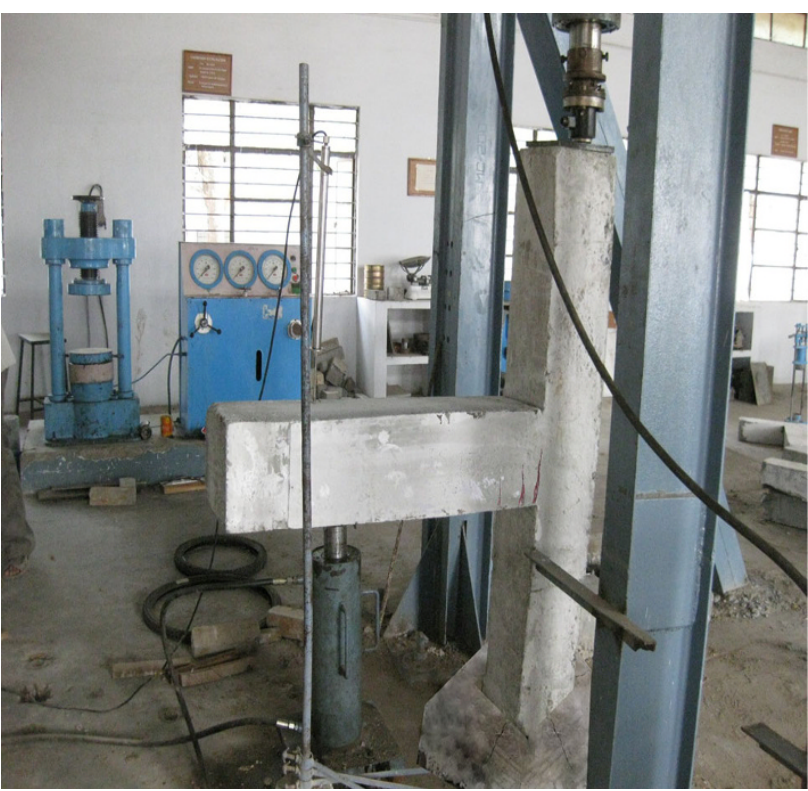

Fig. 7 Experimental test set-up of exterior beam-column joint

beam. One number of linear variable differential transducers (LVDTs) was used to measure the deformations of beam. The schematic diagram of monotonic loading test set-up is shown in Fig. 6.

\section{Results and discussion}

Experimental test set-up

The experimental test set-up of exterior beam-column joint is shown in Fig. 7.

\section{Load-carrying capacity}

Exterior beam-column joint was tested in a frame-testing machine. The applied load was measured by means of load cell and deflection created for each load was measured by using LVDTs. The results for the test specimens are shown in Table 2. Yield load and ultimate load for each specimen were compared in Fig. 8.

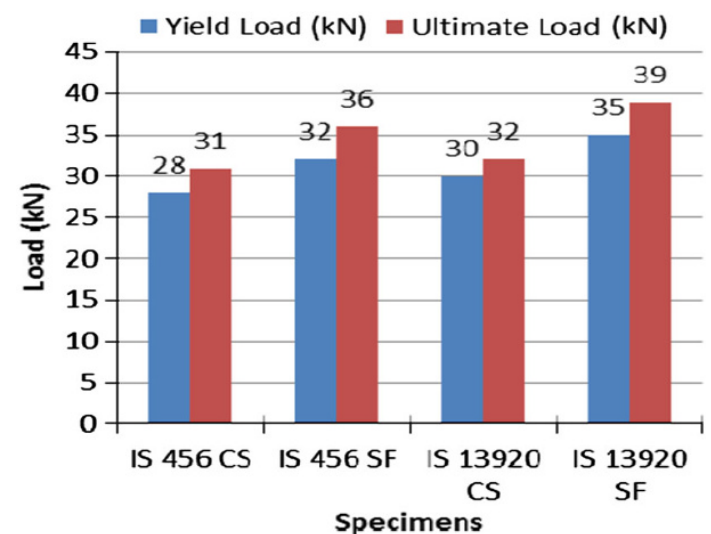

Fig. 8 Comparison of yield load and ultimate load of each specimens

Crack pattern of specimens

Diagonal cracks were noticed more at the joint of the control specimens with reinforcement detailing as per IS 456-(2000) and IS 13920-(1993) compared to the specimens casted by using HPC mix with $10 \%$ silica fume and $0.3 \%$ glass fibre. The provision of cross-diagonal bars at the joint reduces the congestion of reinforcement and also formations of diagonal cracks were reduced. All the specimens have increased load-carrying capacity and reduction of diagonal cracks compared to the specimens designed without cross-diagonal bars in the previous research works (Figs. 9, 10, 11, 12).

Load vs. deflection characteristics

In the load versus deflection characteristics, ultimate load and ultimate deflection were compared for each specimen as shown in Fig. 13. IS 456 with SF specimen had high, ultimate load-carrying capacity and lower deflection than IS 456 control specimen by $16 \%$. IS 13920 with SF specimen had high, ultimate load-carrying capacity and lower deflection than IS 13920 control specimen by $22 \%$.

It is concluded from the load versus deflection characteristics graph that specimens having HPC mix with silica fume and glass fibre showed better ultimate

Table 2 Details of specimens and test results

\begin{tabular}{|c|c|c|c|c|c|c|}
\hline Specimen & $\begin{array}{l}\text { Reinforcement } \\
\text { detailing }\end{array}$ & Concrete mix & $\begin{array}{l}\text { Yield load } \\
(\mathrm{kN})\end{array}$ & $\begin{array}{l}\text { Ultimate } \\
\text { load }(\mathrm{kN})\end{array}$ & $\begin{array}{l}\text { Deflection at } \\
\text { ultimate load } \\
(\mathrm{mm})\end{array}$ & $\begin{array}{l}\text { Stiffness at } \\
\text { ultimate load } \\
(\mathrm{kN} / \mathrm{mm})\end{array}$ \\
\hline IS $456 \mathrm{CS}$ & IS 456-(2000) & HPC mix (control specimen) & 28 & 31 & 36.69 & 0.84 \\
\hline IS $456 \mathrm{SF}$ & IS 456-(2000) & HPC mix with $10 \% \mathrm{SF}$ and $0.3 \% \mathrm{GF}$ & 32 & 36 & 31 & 1.16 \\
\hline IS $13920 \mathrm{CS}$ & IS 13920-(1993) & HPC mix (control specimen) & 30 & 32 & 33.17 & 0.96 \\
\hline IS $13920 \mathrm{SF}$ & IS 13920-(1993) & HPC mix with $10 \% \mathrm{SF}$ and $0.3 \% \mathrm{GF}$ & 35 & 39 & 29.47 & 1.32 \\
\hline
\end{tabular}




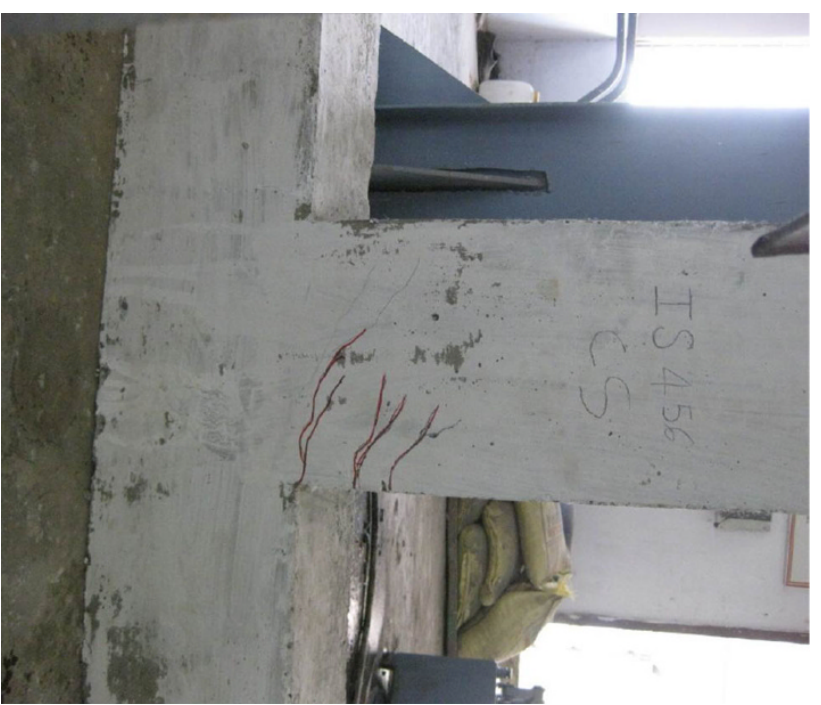

Fig. 9 Crack pattern of IS 456 CS

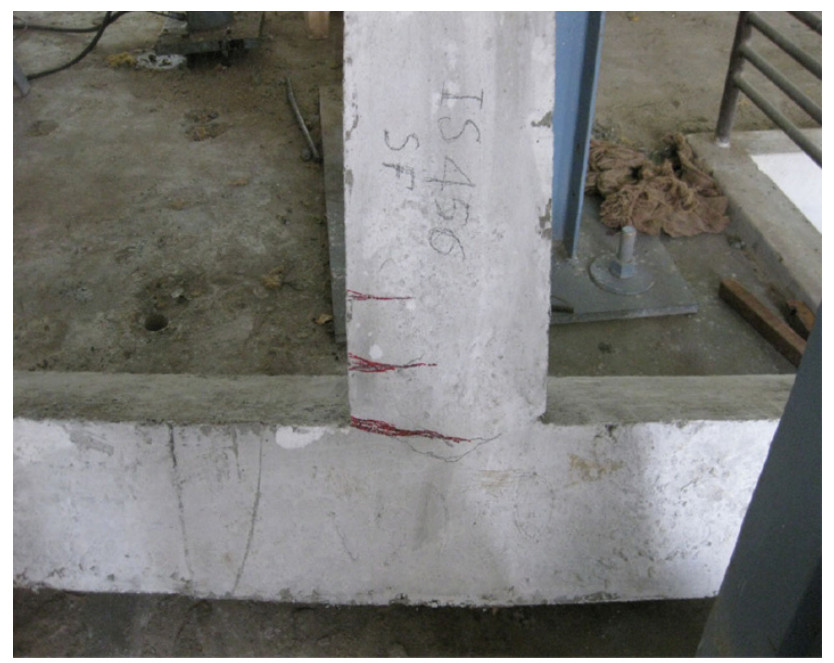

Fig. 10 Crack pattern of IS 456 with SF

load-carrying capacity and lower deflection than specimens having HPC mix for both the reinforcements detailing.

Stiffness vs. deflection characteristics

In the stiffness versus deflection characteristics, stiffness at ultimate load was compared with each specimen as shown in Fig. 14. As the stiffness of the specimen is increased, the density would be greater for the specimens, and the strength of the specimens would be high and with high ultimate carrying capacity (Fig. 15).

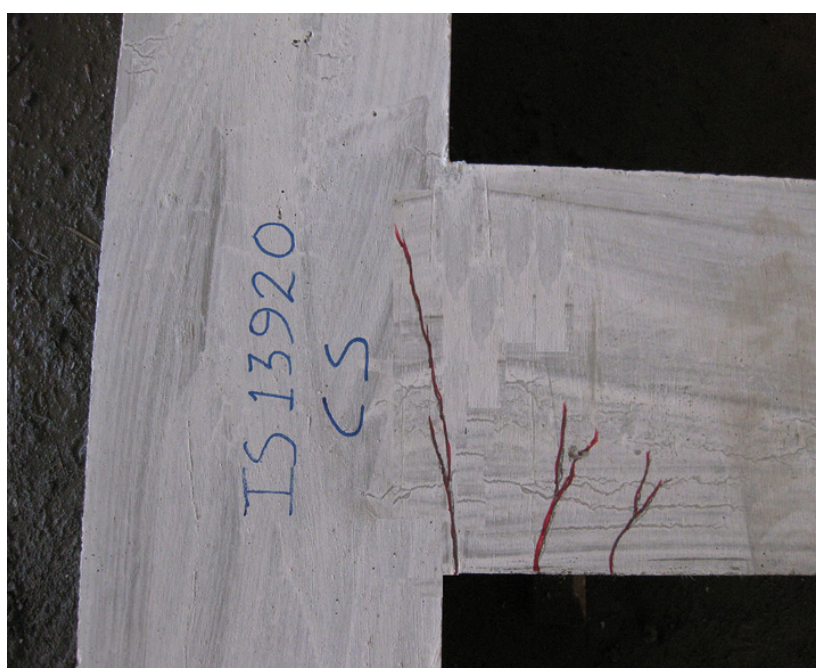

Fig. 11 Crack pattern of IS 13920 CS

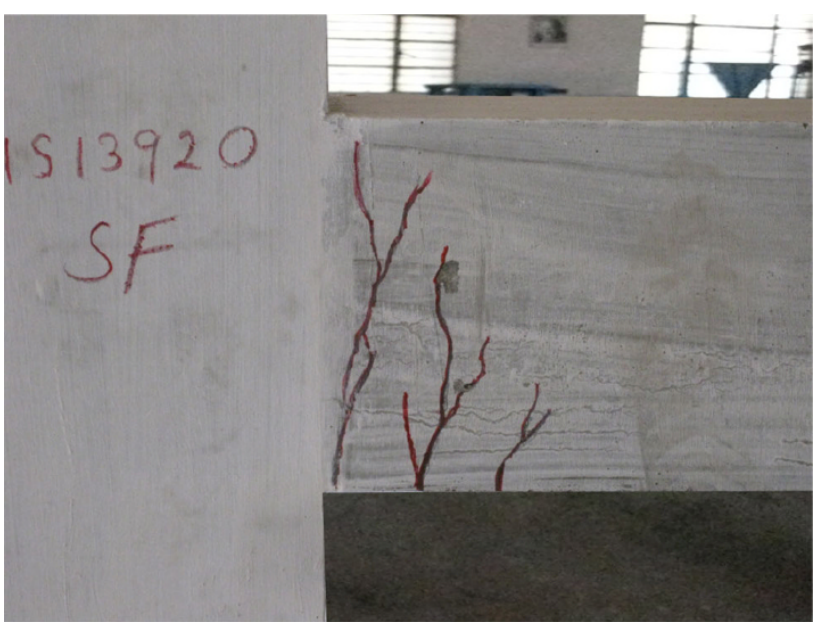

Fig. 12 Crack pattern of IS 13920 with SF

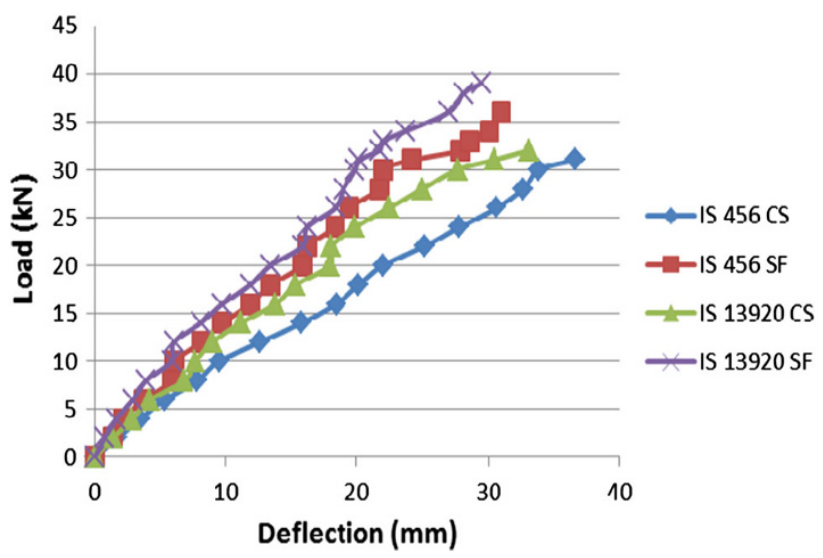

Fig. 13 Load vs. deflection graph 


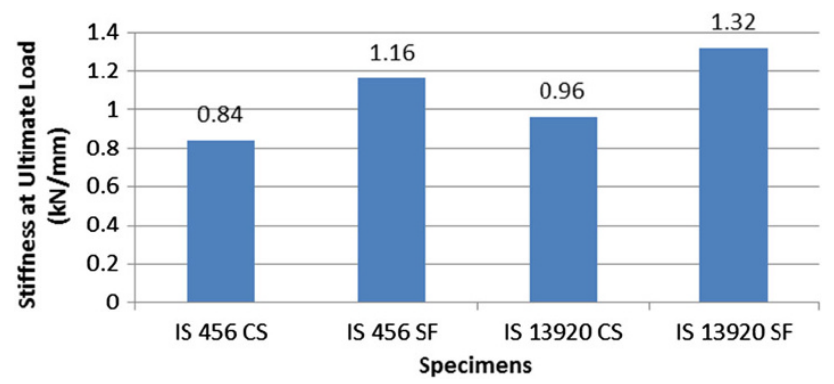

Fig. 14 Comparison of stiffness of each specimens

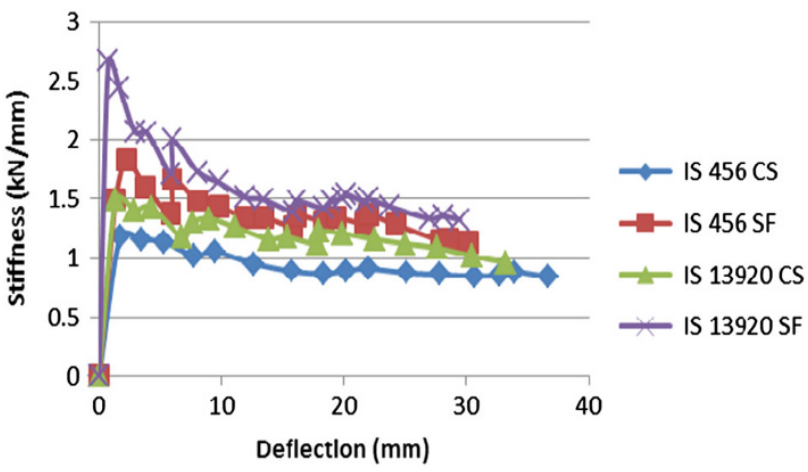

Fig. 15 Stiffness vs. deflection graph

\section{Conclusion}

In this paper, the performances of exterior beam-column joint with two Indian standard codes were examined experimentally. The following conclusions are arrived at from this study:

- The behaviour of exterior beam-column joint specimens in which the reinforcement designed as per IS 456-(2000) and IS 13920-(1993) under monotonic loading was studied.

- The test specimens with silica fume and glass fibre in HPC mix showed better performance in both the reinforcements detailing as per IS 456-(2000) and IS 13920-(1993) with cross-diagonal bars at the joint exhibiting higher strength with minimum cracks in the joint.

- The test specimens with silica fume and glass fibre in HPC mix showed increased ultimate load-carrying capacity and lesser deflection than the control specimens with HPC mix.

- The ultimate load-carrying capacity of specimens with silica fume for both construction code reinforcement detailing and ductile code reinforcement detailing was increased by 16 and $22 \%$, respectively, compared to the control specimens with similar reinforcement detailing.

- Specimens with silica fume and glass fibre in the HPC mix have higher stiffness values compared to the specimens with HPC mix by $38 \%$.

Open Access This article is distributed under the terms of the Creative Commons Attribution License which permits any use, distribution, and reproduction in any medium, provided the original author(s) and the source are credited.

\section{References}

ACI 211.4R (1993) (Reapproved 1998) Guide for selecting proportions for high strength concrete with Portland cement and fly ash. Reported by ACI Committee p 211

Bindhu KR, Jaya KP (2008) Performance of exterior beam column joint with cross-inclined bars under seismic loading. J Eng Appl Sci 3(7):591-597

Bindhu KR, Jaya KP (2010) Strength and behaviour of exterior beamcolumn joint with diagonal cross bracing bars. Asian J Civ Eng (Build Hous) 11(3):397-410

Ganeshan N, Indira PV, Abraham Ruby (2007) Steel fibre reinforced high performance concrete beam-column joints subjected to cyclic loading. ISET J Earthq Eng 44(3-4):445-456

IS 12269-1987 (Reaffirmed 1999) Specification for 53 grade ordinary Portland cement. Bureau of Indian Standards, New Delhi, India

IS 13920-1993 (Reaffirmed 1998) Ductile detailing of reinforced concrete structures subjected to seismic forces code of practice. Bureau of Indian Standards, New Delhi, India

IS 516-1959 (Reaffirmed 1997) Methods of tests for strength of concrete. Bureau of Indian Standards, New Delhi, India

IS 383-1970 (Reaffirmed 1997) Specification for coarse and fine aggregate from natural sources for concrete. Bureau of Indian Standards, New Delhi, India

IS 456-2000 (Fourth Revision) Plain and reinforced concrete -code of practice. Bureau of Indian Standards, New Delhi, India

Kumar V, Nautiyalil BD, Kumar S (1991) A study of exterior beamcolumn joints. Indian Concr J 55(2):39-43

Malathy R, Subramanian K, Rameshkumar M (2007) Effect of glass fibre on restrained plastic shrinkage cracking of HPC with silica fume. J Sci Ind Res 66:748-751

Perumal P, Thanukumari B (2010) Seismic performance of hybrid fibre reinforced beam-column joint. Int J Civi Struct Eng 1(3):749-774 